\title{
Effects of atmospheric lead on soil microbiota in Kuwait
}

\author{
A. S. Al-Dousari, K. Majki, S. Moustafa \& E. Al-Saleh \\ Microbiology Program, Department of Biological Sciences, \\ Faculty of Science, Kuwait University, Kuwait
}

\begin{abstract}
The increase in human population is usually associated with increased waste production and by-products of urbanization. One such product of urbanization is heavy metals such as lead that at high concentrations have detrimental effects on human health as established previously. However, little is known about the effects of lead on the growth, activity and community of soil microbiota. For this purpose, the effects of lead on the microbiota of roadside soil samples collected from different distances from main roads in Kuwait were investigated. The addition of lead to soils decreased significantly $(\mathrm{P}<0.05)$ the counts and respiration of the total heterotrophic bacteria in particular in soils harbored lower concentrations of lead. Furthermore, the identification of soil bacteria showed the dominance of Gram-negative bacteria with high potentials to tolerate multiplicity of heavy metals where the order of increasing toxicity of heavy metals on tested bacteria was lead $<$ chromium $<$ aluminium $<$ cobalt $<$ nickel $<$ mercury $<$ cadmium. Moreover, based on 16S-RFLP analyses, it was demonstrated that soils containing higher concentrations of lead harboured less diverse bacterial communities. Results suggested that changes in soil microbiota are attributed to atmospheric lead apparently originated from car emissions.

Keywords: metal-resistant Gram-negative bacteria, lead-resistant bacteria, roadside soil contamination, soil microbiota.
\end{abstract}

\section{Introduction}

Roadside soil is a major sink of heavy metals (e.g. lead, zinc, cadmium, chromium, nickel, and copper) and hydrocarbons pollutants (e.g. gasoline, gas oil, and kerosene) in the environment [1] such as roadside soils [2]. Lead is used 
as lead alkyl additive for motor vehicle fuel (petroleum), thus, the combustion of such fuels probably resulted in the deposition of lead on surface soils [3, 4]. There are other sources of heavy metals pollutants introduced to the environment e.g. yellow and red road markings, and gray paint or anticorrosives which are sources of lead pollution. In addition, gasoline, diesel soot, tire rubber and asphalt are considered as sources of many heavy metals pollution (e.g., As, $\mathrm{Ni}$, $\mathrm{Zn}, \mathrm{Cd}, \mathrm{Zn}, \mathrm{Ni}$ and $\mathrm{V}$ metals) [1]. Heavy metal concentrations in roadside soil vary with the variation in the distance from road edge, the depth of soil, and the traffic density on the road (number of motor vehicle running on petrol or diesel fuel). Thus, an increase in the number of motor vehicles is expected to increase the levels of road-side pollution especially heavy metals $[2,5]$. Heavy metal concentrations decrease with increasing distance from the road, because of the gravity that pull down the heavy metals emitted from the motor vehicles on the road to settle near the edge. With increasing the soil depth, metal concentrations decrease owing to their leaching during passing through the soil particles dawn from the top of the soil. Kuwait environment is at risk from various atmospheric pollutants for instance lead originating from several sources such as car exhausts and industries such as the petrochemical plants, power desalination plants, fertilizer-production plant, the melamine company, the industrial gas corporation and the paper products company [6]. These industries discharged their dangerous wastes containing organic and inorganic (heavy metals) compounds to the environment and cause harmful effects to human and all living organisms [6]. The aim of the current study was to investigate the effects of lead on the count, activity and diversity of total heterotrophic bacteria in soils located close and far from busy main roads in Kuwait. Correlation between lead concentration in soils and the potential of soil bacteria to tolerate lead was also assessed.

\section{Materials and methods}

\subsection{Collecting of soil samples}

Soil samples were collected using the method of Al-Saleh and Obuekwe [7] from the Sixth Ring Road and Al-Jahra Highway roadside sites north of Kuwait. At each site, soils were collected from two locations. The first location was approximately three meters far from the road and second location was about two hundred meters far from the road. The soil samples collected from the Sixth Ring Road location were designated 6C (three meters far from the road) and 6F (two hundred meters far from the road) soils. Also, soil samples collected from the AlJahra Highway roadside were designated JC (three meters far from the road) and JF (two hundred meters far from the road) soils.

\subsection{Determination of heavy metals concentrations in soil samples}

The method of Rowell [8] was employed for the determination of heavy metals concentrations in soil by atomic absorption spectroscopy (AAS) after acid digestion of soil. 


\subsection{Enumeration of total heterotrophic bacteria in soil samples}

Four portions from soil samples were pooled, thoroughly mixed, and passed through a sieve (mesh size, $2 \mathrm{~mm}$ ). Ten grams (wet weight) of soil was suspended in $40 \mathrm{ml}$ sterile distilled water; mixed thoroughly for 2 hours to release the adhering bacteria and kept overnight to settle down the soil particles. Aliquots $(0.1 \mathrm{ml})$ of the clear supernatant of the soil suspension, in direct and its dilutions $\left(10^{-1}-10^{-4}\right)$ were spread on nutrient agar plates [9] with different lead concentrations $\left(0-3,5\right.$, and $\left.10 \mathrm{mg} \mathrm{ml}^{-1}\right)$. The plates were incubated at $30^{\circ} \mathrm{C}$ for up to 24 hours, and the grown total heterotrophic bacterial colonies (THB) were counted.

\subsection{Isolation and molecular identification of the isolated heterotrophic bacteria}

Heterotrophic bacteria from roadside soil samples were isolated on nutrient agar plates supplemented with different concentrations of lead $(0,2,5$, and $10 \mathrm{mg} \mathrm{ml}^{-1}$ ) and were incubated in a desiccator at $30^{\circ} \mathrm{C}$ for up to 7 days [9]. DNA extracted from the isolated bacteria and used for the amplification of the $16 \mathrm{~S}$ rDNA gene, and then DNA sequencing and Sequencing Analysis v5.2 Software (Applied Biosystem, USA) was used to analyze the sequences that were compared to other sequences in the GenBank database using BLAST [10].

\subsection{Effects of heavy metals on the growth of isolated bacteria (Wells diffusion methods)}

The effects of lead and heavy metals (aluminium, cadmium, cobalt, chrome, lead mercury and nickel) on the growth of the isolated bacteria were determined using the agar well diffusion method of Lertcanawanichakul and Sawangnop [11].

\subsection{Effect of lead on respiration of isolated bacteria}

The effect of lead $(0,0.1,0.5$ and $1.0 \mathrm{mg} \mathrm{ml} 1)$ on respiration of the isolated bacteria was determined in a Micro-Oxymax respirometer (Columbus Instruments, USA), method of Al-Saleh and Obuekwe [7] was followed.

\section{Results}

\subsection{Heavy metal content of soils}

Most heavy metal concentrations were higher in Al-Jahra Highway soils compared to those of the Sixth Ring Road soils (Table 1). In fact, the soils which were closer to the road showed higher concentrations of heavy metals compared to those determined in soils collected two hundred meters away from the road. 
Table 1: Heavy metal content of soils.

\begin{tabular}{|c|c|c|c|c|}
\hline $\begin{array}{r}\text { Heavy } \\
\text { metal }\end{array}$ & 6C Soil & 6F Soil & JC soil & JF Soil \\
\hline $\mathrm{Co}$ & 0.80 & 0.63 & 1.46 & 0.83 \\
\hline $\mathrm{Ni}$ & 4.00 & 3.74 & 8.92 & 4.09 \\
\hline $\mathrm{Cr}$ & 4.65 & 4.0130 & 9.89 & 5.21 \\
\hline $\mathrm{Pb}$ & 23.7 & 18.5 & 19.8 & 17.6 \\
\hline $\mathrm{Al}$ & 2650 & 2089 & 4424 & 2693 \\
\hline
\end{tabular}

The units of all concentrations are in $\mathrm{mg}-1 \mathrm{~kg}$; ND, not detected

\subsection{Enumeration of bacteria in soil}

The numbers of the total heterotrophic bacteria isolated from soil samples in the absence and presence of lead were determined and are presented in Table 2. Higher counts were detected in soils located closer to the main road that harboured higher concentrations of lead.

Table 2: $\quad$ Counts of total heterotrophic bacteria in soil in the presence of lead.

\begin{tabular}{|c|c|c|c|c|}
\hline $\begin{array}{c}\text { Lead } \\
\text { added } \\
\left(\mathrm{mg} \mathrm{m}^{-1}\right)\end{array}$ & $\begin{array}{c}\mathrm{JC} \mathrm{Soil}_{(\mathrm{CFU} \mathrm{g}}^{-1} \\
\text { soil })\end{array}$ & $\begin{array}{c}\text { JF Soil } \\
\left(\mathrm{CFU} \mathrm{g}^{-1} \text { soil }\right)\end{array}$ & $\begin{array}{c}\text { 6C Soil } \\
\left(\mathrm{CFU} \mathrm{g}^{-1} \text { soil }\right)\end{array}$ & $\begin{array}{c}\text { 6F Soil } \\
\left(\mathrm{CFU} \mathrm{g}^{-1} \text { soil }\right)\end{array}$ \\
\hline Nil & $6.54 \times 10^{6}$ & $9.42 \times 10^{4}$ & $1.38 \times 10^{5}$ & $4.03 \times 10^{4}$ \\
\hline 1 & $2.51 \times 10^{5}$ & $2.52 \times 10^{3}$ & $5.82 \times 10^{3}$ & $1.55 \times 10^{3}$ \\
\hline 2 & $1.21 \times 10^{5}$ & $2.40 \times 10^{2}$ & $3.13 \times 10^{3}$ & 80 \\
\hline $3-10$ & $\mathrm{Nil}$ & $\mathrm{Nil}$ & $\mathrm{Nil}$ & Nil \\
\hline
\end{tabular}

\subsection{Identification of the isolated lead-resistant bacteria}

Two hundred and seven lead-resistant bacteria were isolated from the all soils and identified by sequencing of the $16 \mathrm{~S}$ rDNA gene. Sixty nine bacteria were isolated from JC soil. These bacteria belonged to nine different bacterial genera. Also, ten different bacterial genera were identified in the JF soil. In addition, twelve different bacterial genera were identified in the $6 \mathrm{C}$ soil as shown in Table 3. Moreover, sixteen different bacterial genera were identified in the $6 \mathrm{~F}$ soil as shown in Table 4. 
Table 3: Identities of bacteria isolated from $6 \mathrm{C}$ soil amended with $2 \mathrm{mg} \mathrm{Pb} \mathrm{ml}^{-1}$.

\begin{tabular}{|c|c|}
\hline Identity & Number of isolates \\
\hline Pseudomonas spp. & 14 \\
Pseudomonas luteola & 6 \\
Pseudomonas brassicacearum & 7 \\
\hline Duganella violaceusniger & 2 \\
\hline Variovorax paradoxus & 2 \\
\hline Cupriavidus respiraculi & 2 \\
\hline Erwinia spp. & 2 \\
\hline Roseomonas genomospecies & 1 \\
\hline Massilia lutea & 1 \\
Massilia timonae & 1 \\
\hline Massilia dura & 1 \\
\hline Ralstonia spp. & 1 \\
\hline Arthrobacter spp. & 1 \\
\hline Janthinobacterium spp. & 1 \\
\hline Paracraurococcus spp. & 1 \\
\hline Acinetobacter spp. & \\
\hline Total number of isolated strains $=45$ \\
\hline
\end{tabular}

Table 4: Identities of bacteria isolated from $6 \mathrm{~F}$ soil amended with $2 \mathrm{mg} \mathrm{Pb} \mathrm{ml}^{-1}$.

\begin{tabular}{|c|c|}
\hline Identity & Number of isolates \\
\hline Duganella violaceusniger & 13 \\
\hline Pseudomonas spp. & 9 \\
Pseudomonas luteola strain Marseille & 4 \\
Pseudomonas luteola & 2 \\
Pseudomonas brassicacearum & 2 \\
Pseudomonas fluorescens & 1 \\
\hline Ralstonia spp. & 5 \\
\hline Roseomonas genomospecies & 4 \\
Roseomonas spp. & 2 \\
Roseomonas aquatic & 1 \\
\hline Azospirillum lipoferum & 4 \\
Azospirillum zeae & 2 \\
\hline Arthrobacter aurescens & 3 \\
Arthrobacter globiformis & 3 \\
Arthrobacter spp. & 2 \\
\hline Rhodococcus spp. & 1 \\
\hline Massilia spp. & 3 \\
Massilia lutea & 1 \\
\hline Cupriavidus respiraculi & 3 \\
\hline Kocuria spp. & 2 \\
\hline Georgenia spp. & 1 \\
\hline Staphylococcus haemolyticus & 1 \\
\hline Bacillus spp. & 1 \\
\hline Agrococcus jenensis & 1 \\
\hline Sinorhizobium spp. & 1 \\
\hline Planomicrobium spp. & 1 \\
\hline Total number of isolated strains $=73$ \\
\hline
\end{tabular}




\subsection{Effect of heavy metals on the growth of isolated bacteria}

The effects of heavy metals on isolated bacteria were determined using the welldiffusion method. Results demonstrated the potential of isolated bacteria to tolerate multiple heavy metals (Tables 5 and 6). Based on the sizes of the inhibition zone determined, lead demonstrated to have the least toxic effects on the growth of tested bacteria compared to other metals while cadmium showed the highest toxic inhibitory effects (Tables 5 and 6).

Table 5: Effects of heavy metals on the growth of isolated bacteria from 6C soil.

\begin{tabular}{|c|c|c|c|c|c|c|c|}
\hline $\begin{array}{c}\text { Diameter of } \\
\text { inhibition zone } \\
(\mathrm{cm})\end{array}$ & \multicolumn{7}{|c|}{$\begin{array}{c}\text { Number of bacteria tested } \\
(\%)\end{array}$} \\
\cline { 2 - 9 } & $\mathrm{Cd}$ & $\mathrm{Al}$ & $\mathrm{Cr}$ & $\mathrm{Ni}$ & $\mathrm{Hg}$ & $\mathrm{Co}$ & $\mathrm{Pb}$ \\
\hline$\leq 1.5$ & $\mathrm{Nil}$ & 21.05 & 73.68 & 5.26 & 5.27 & 10.53 & 100 \\
\hline $1.5-3.5$ & 47.37 & 78.95 & 26.32 & 84.21 & 26.32 & 89.47 & Nil \\
\hline$\geq 3.5$ & 52.63 & Nil & Nil & 10.53 & 68.42 & Nil & Nil \\
\hline
\end{tabular}

Table 6: Effects of heavy metals on the growth of isolated bacteria from $6 \mathrm{~F}$ soil.

\begin{tabular}{|c|c|c|c|c|c|c|c|}
\hline \multirow{2}{*}{$\begin{array}{c}\text { Diameter of } \\
\text { inhibition zone } \\
(\mathrm{cm})\end{array}$} & \multicolumn{7}{|c|}{$\begin{array}{c}\text { Number of bacteria tested } \\
(\%)\end{array}$} \\
\cline { 2 - 9 } & $\mathrm{Cd}$ & $\mathrm{Al}$ & $\mathrm{Cr}$ & $\mathrm{Ni}$ & $\mathrm{Hg}$ & $\mathrm{Co}$ & $\mathrm{Pb}$ \\
\hline$\leq 1.5$ & $\mathrm{Nil}$ & 35.71 & 42.86 & 21.43 & 21.43 & 21.43 & 92.9 \\
\hline $1.5-3.5$ & 14.29 & 64.29 & 57.14 & 50 & 7.14 & 71.43 & 7.14 \\
\hline$\geq 3.5$ & 85.71 & Nil & Nil & 28.57 & 71.43 & 7.14 & Nil \\
\hline
\end{tabular}

\subsection{Effects of lead on bacterial respiration}

The amount of carbon dioxide evolved from the respiration of tested bacteria in the presence of different concentrations of lead was determined. Results demonstrated that, the presence of higher amounts of lead resulted in higher inhibitory effects on bacterial respiration (Table 5). The inhibitory effects of lead varied with different bacteria tested.

\section{Discussion}

The higher concentrations of heavy metals in the 6C and JC soil samples compared to that in the $6 \mathrm{~F}$ and JF soils (Table 1) could be due to the close location of the sampling sites of $6 \mathrm{C}$ and JC soils to the main road that has been reported to be a source of heavy metals from cars' exhausts [12, 13]. In addition, 
given that heavy metals were reported to have lethal effects on bacteria [14-16], thus, the presence of higher concentrations of heavy metals in the $6 \mathrm{C}$ and JC soil samples compared to that in the $6 \mathrm{~F}$ and $\mathrm{JF}$ soils is anticipated to apply higher inhibitory effects on the growth and activity of soil microbiota of $6 \mathrm{C}$ and JC soil samples. As can be seen in Table 2, the counts of the THB decreased significantly $(\mathrm{P}<0.05)$ in all soil samples after the additions of lead in particular in $6 \mathrm{~F}$ and $\mathrm{JF}$ soils where the decrease in THB counts were significantly higher $(\mathrm{P}<0.05)$ compared to the decrease in $6 \mathrm{C}$ and $\mathrm{JC}$ soils which could be due to the adaptation of $6 \mathrm{C}$ and $\mathrm{JC}$ soil microbiota to higher concentrations of lead originating from car emissions [17] which are the only apparent difference between the $6 \mathrm{C} / \mathrm{JC}$ and $6 \mathrm{~F} / \mathrm{JF}$ soils.

Furthermore, the identification of the isolated bacteria from all collected soils showed the dominance of Gram-negative (Tables 3 and 4) which indicated the higher ability of Gram-negative bacteria to adapt and evolve mechanisms to survive in soils containing various types of pollutants which was in agreement with previous studies that showed the abundance of Gram-negative bacterial populations in contaminated soils [18-21]. In the current study, it was shown that, the collected soils harbored abundance of the Gram-negative bacterium Pseudomonas (Tables 3 and 4) which is a significant constituent of the natural microbial ecosystem, involved in the biodegradation of various organic pollutants and xenobiotics $[22,23]$. The occurrences and dominance of the genus Pseudomonas in the Kuwaiti environments were documented previously [24] which was unsurprising due to wide spread of pollution in the Kuwait environment [25] and the high adaptable nature of Pseudomonad to polluted environments [26]. However, some of the isolated bacteria such as Erwinia and Cupriavidus respiraculi are considered medically important bacteria $[27,28]$ that constituted potential source of human health hazards. The occurrence of medically significant microbiota in environmental samples was reported previously [29-31].

Moreover, based on the size of the diameter of inhibition zones determined, some tested bacteria were categorized as sensitive to heavy metals and demonstrated zone of inhibition of $\geq 3.5 \mathrm{~cm}$. In fact, the majority of sensitive bacteria were recorded in the presence of cadmium and mercury, respectively. On the other hand, the majority of bacteria with high potentials to tolerate heavy metals that demonstrated zone of inhibition of $\leq 1.5 \mathrm{~cm}$ and were depicted in the presence of lead and chromium, respectively (Tables 5 and 6). Accordingly, based on the well diffusion method, the order of increasing toxicity of heavy metals on tested bacteria was lead $<$ chromium $<$ aluminium $<$ cobalt $<$ nickel $<$ mercury $<$ cadmium which was in agreement with earlier reports signifying the high inhibitory effects of cadmium, mercury and nickel to bacteria [32-37]. Moreover, the addition of lead to the growing bacterial cultures resulted in significant $(\mathrm{P}<0.05)$ decrease in bacterial respiration in particular those isolated from soils contained low concentration of lead (Table 7). These results were in. agreement with previous reports demonstrating the potential of lead to inhibit bacterial respiration [7]. However, the addition of increasing concentrations of lead to some bacterial strains demonstrated insignificant decrease $(\mathrm{P}<0.05)$ in 
bacterial respiration which could be due to potentials of these bacteria to resist the inhibitory effects of lead.

Table 7: $\quad$ Effects of lead on respiration of the isolated bacteria.

\begin{tabular}{|c|c|c|c|c|}
\hline \multirow{2}{*}{$\begin{array}{c}\text { Source } \\
\text { of } \\
\text { bacteria }\end{array}$} & Bacteria & \multicolumn{3}{|c|}{ Amount of carbon dioxide evolved (\%) } \\
& & \multicolumn{3}{|c|}{ Lead concentrations $\left(\mathrm{mg} \mathrm{ml}^{-1}\right)$} \\
\hline \multirow{3}{*}{ 6C Soil } & & 0.1 & 0.5 & 1 \\
\cline { 2 - 5 } & Duganella violaceusniger & 55.0 & 49.6 & 31.5 \\
& Cupriavidus respiraculi & 98.5 & 81.0 & 76.4 \\
& Pseudomonas luteola & 100 & 85.3 & 75.6 \\
\hline \multirow{3}{*}{ 6F Soil } & Sinorhizobium spp & 97.4 & 82.2 & 63.4 \\
& Cupriavidus respiraculi & 100 & 76.7 & 66.9 \\
& Massilia spp. & 36.7 & 13.6 & 9.77 \\
\hline \multirow{3}{*}{ JF Soil Soil } & Erwinia spp. & 37.3 & 30.82 & 22.89 \\
& Massilia dura & 92.5 & 86.80 & 67.22 \\
& Ralstonia spp. & 50.4 & 46.3 & 41.5 \\
\hline & Pseudomonas luteola & 95.41 & 62.17 & 26.04 \\
& Ralstonia spp. & 70.21 & 61.50 & 21.96 \\
\hline
\end{tabular}

Results represent percentages of the controls (experiments conducted in the absence of lead) that were considered as 100 .

\section{Conclusions}

The presence of varying concentrations of heavy metals in Kuwaiti soils selected adapted bacteria that dominated soil samples and showed the potential to tolerate varying concentrations of heavy metals in particular lead. The potential of isolated bacteria to tolerate varying concentrations of lead correlated well with the concentrations of lead detected in the two soil types where bacteria isolated from soils located closer to the main road demonstrated higher tolerance to lead compared to those isolated from soils located relatively far from the main roads. Apparently, atmospheric lead originating most probably from car exhausts was the source of the higher concentrations of lead in soil samples located closer to the main roads.

\section{Acknowledgements}

We would like to thank the College of Graduate Studies (Kuwait University) and sincerely acknowledge the Kuwait Foundation for the Advancement of Sciences for supporting our work. 


\section{References}

[1] Ozaki, H., Watanabe, I., and Kuno, K., Investigation of the heavy metal sources in relation to automobiles. Water, air, and soil pollution, 157, pp. 209-223, 2004.

[2] Amusan, A.A., Badaz, S. B. and Salami, A. T., Effect of traffic density on heavy metal content of soil and vegetation along roadsides Osun Stat, Nigeria. West Africa Journal of Applied Ecology, 4, pp. 107-114, 2003.

[3] Huang, P.M., Berthelin, J., Bollag, J.M., Mcgill, W.B., and Page, A.L., (eds). Environmental Impact of soil component interactions: metals, other soil component interactions, Effect of microorganisms on mobility of heavy metals in soils. Publications: Lewis Publishers is an imprint of CRC press, United States of America, 1995.

[4] Mielkea, H.W., Wang, G., Gonzalesa, C.R., Leb, B., Quachb, V.N., and Mielkec, P.W., PAH and metal mixtures in New Orleans soils and sediments. The science of the total environment, 281, pp. 217-227, 2001.

[5] Pagotto, C., Rémy, N., Legret, M., and Cloirec, L.P., Heavy metal pollution of road dust and roadside soil near a major rural highway. Environmental technology, 22, pp. 307-319, 2001.

[6] Beg, M. U., Saeed, T., Al-Muzaini, S., Beg, K. R., and Al-Bahloul, M., Distribution of petroleum hydrocarbon in sediment from coastal area receiving industrial effluents in Kuwait. Ecotoxicology and environmental safety, 54, pp. 47-57, 2003.

[7] Al-Saleh, E.S. and Obuekwe, C., Inhibition of hydrocarbon bioremediation by lead in a crude oil-contaminated soil. International Biodeterioration and Biodegradation, 56, pp. 1-7, 2005.

[8] Rowell D.L. (ed). Soil science, Pesticides and metals. Publications: Addison Wesley Longman Limited, Essex, 1994.

[9] Cohen-Bazire G., Sistrom W.R., and Stainer R.Y., Kinetic studies of pigment synthesis by non-sulfur purple bacteria. Journal of cellular physiology, 49, pp. 25-68, 1957.

[10] Altschul, S.F., Madden, T.L., Schäffer, A.A, Zhang, J., Zhang, Z., Miller, W. and Lipman, D.J., Gapped BLAST and PSI-BLAST: a new generation of protein database search programs. Nucleic Acids Research, 25(17), pp. 3389-3402, 1997.

[11] Lertcanawanichakul, M. and Sawangnop, S., A comparison of two methods used for measuring the antagonistic activity of Bacillus species. Walailak journal of science and technology, 5, pp. 161-171, 2008.

[12] Lagerwerff, J.V., and Specht, A. W., Contamination of roadside soil and vegetation with cadmium, nickel, lead, and zinc. Environment science and technology, 4 (7), pp. 583-586, 1970.

[13] Jaradat, Q.M. and Momani, K.A., Contamination of roadside soil, plants, and air with heavy metals in Jordan, a comparative study. Turkish journal of chemistry, 23, pp. 209-220 1999.

[14] Hughes, M. F., Arsenic toxicity and potential mechanisms of action. Toxicology letters, 13, pp. 1-16, 2002. 
[15] Duxbury, T., Toxicity of heavy metals to soil bacteria. FEMS microbiology letter, 11, pp. 217-220, 1981.

[16] Babich, H. and Stotzky, G., Toxicity of zinc to fungi, bacteria, and coliphages: influence of chloride ions. Applied and Environmental Microbiology, 36, pp. 906-914, 1978.

[17] Iurchenko, V. and Mykhailova, L. (2011), “ Impact of highway on soils ecosystems of the roadside area", The 7th International Conference on Transbaltica, Vilnius Gediminas Technical University Transport Engineering Faculty, Vilnius, Lithuania, 5-6 May 2011.

[18] Gutierrez, A.-J., Figueras, A., Albaiges, J., Jimenez, N., Vinas, M., Solanas, A. M. and Novoa, B., Bacterial communities from shoreline environments (Costa da Morte, Northwestern Spain) affected by the prestige oil spill. Applied and Environmental Microbiology, 75, pp. 3407-3418, 2009.

[19] Margesin, R., Labbé, D., Schinner, F., Greer, C.W., and Whyte, L.G., Characterization of hydrocarbon-degrading microbial populations in contaminated and Pristine Alpine soils. Applied and environmental microbiology, 69, pp. 3085-3092, 2003.

[20] Saadoun, I., Mohammad, M.J., Hameed, K.M. and Shawaqfah, M., Microbial populations of crude oil spill polluted soils at the Jordan-Iraq desert (the Badia region). Brazilian journal of microbiology, 39, pp. 453456, 2008.

[21] Hancock, R.E.W., Resistance mechanisms in Pseudomonas aeruginosa and other nonfermentative Gram-negative bacteria. Oxford journals, 27 (1), pp. 593-595, 1998.

[22] Ramos, J., Duque, E., Huertas, M., and Haïdour, A., Isolation and expansion of the catabolic potential of a Pseudomonas putida strain able to grow in the presence of high concentrations of aromatic hydrocarbons. Journal of bacteriology, 177 (14), pp. 3911-3916, 1995.

[23] Rahman, K.S.M., Banat, I.M., Rahman, T-.J., Thayumanavan, T., and Lakshmanaperumalsamy, P., Bioremediation of gasoline contaminated soil by bacterial consortium amended with poultry litter, coir-pith and rhamnolipid biosurfactant. Bioresource technology, 81, pp. 25-32, 2002.

[24] Al-Saleh, E., Drobiova, H., Obuekwe, C., Predominant culturable crude oildegrading bacteria in the coast of Kuwait. International Biodeterioration and biodegradation, 63(4), pp. 400-406, 2009.

[25] Al-Mutairi, N. and Koushki, P., Potential contribution of traffic to air pollution in the state of Kuwait. American Journal of Environmental Sciences, 5 (3), pp. 218-222, 2009.

[26] Tserovska, L., Yordanova, T., and Mehandjiyska, L., Characterization of three bacterial strains biodegradants of aromatic substrates. Journal of culture collections, 4, pp. 43-47, 2005.

[27] Chatterjee, A. and Starr, M.P., Transfer Among Erwinia spp. and Other Enterobacteria of Antibiotic Resistance Carried on R Factors. Journal of bacteriology, 112 (1), pp. 576-584, 1972. 
[28] Vandamme, P. and Coenye, T., Taxonomy of the genus Cupriavidus: a tale of lost and found. International journal of systematic and evolutionary microbiology, 54, pp. 2285-2289, 2004.

[29] Al-Saif, N. and Brazier, J. S., The distribution of Clostridium difficile in the environment of South Wales. Journal of medical microbiology, 45, pp. 133137, 1996.

[30] Santamaría, J. and Toranzos, G.A., Enteric pathogens and soil: a short review. International microbiology, 6, pp. 5-9, 2003.

[31] Wiele, T.V., Vanhaecke, L., Boeckaert, C., Peru, K., Headley, J., Verstraete, W. and, Siciliano, S., Human colon microbiota transform polycyclic aromatic hydrocarbons to estrogenic metabolites. Environmental health perspectives, 113, pp. 6-10, 2005.

[32] Nies, D.H., Microbial heavy-metal resistance. Applied microbiology and biotechnology, 51, pp. 730-750, 1999.

[33] Rosen, B.P., Bacterial resistance to heavy metals and metalloids. Journal of biological inorganic chemistry, 1, pp. 273-277, 1996.

[34] Shakibaie, M.R. and Harati, A., Metal accumulation in Pseudomonas aeruinosa occur in the form of nanoparticles on the cell surface. Iranian journal of biotechnology, 2, pp. 55-60, 2004.

[35] Silver, S. and Phung, L.T., Bacterial heavy metal resistance: new surprises. Annual review of microbiology, 50, pp. 753-789, 1996.

[36] Montuelle, B., Latour, X, Volat, B, and Gounot, A.M., Toxicity of heavy metals to bacteria in sediments. Bulletin of environmental contamination and toxicology, 53, pp. 753-758, 1994.

[37] Ji, G. and Silver, J., Bacterial resistance mechanisms for heavy metals of environmental concern. Journal of industrial microbiology and biotechnology, 14, pp. 61-75, 1995. 